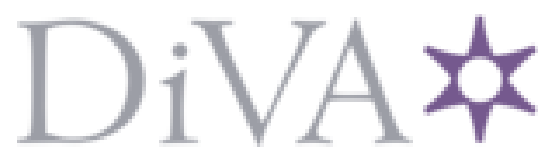

http://www.diva-portal.org

This is the published version of a paper published in Ecological Applications.

Citation for the original published paper (version of record):

Hylander, K., Jonsson, B., Nilsson, C. (2002)

Evaluating buffer strips along boreal streams using bryophtes as indicators.

Ecological Applications, 12(3): 797-806

http://dx.doi.org/10.2307/3060990

Access to the published version may require subscription.

N.B. When citing this work, cite the original published paper.

Permanent link to this version:

http://urn.kb.se/resolve?urn=urn:nbn:se:umu:diva-3870 


\title{
EVALUATING BUFFER STRIPS ALONG BOREAL STREAMS USING BRYOPHYTES AS INDICATORS
}

\author{
Kristoffer Hylander, ${ }^{1,4}$ Bengt Gunnar Jonsson, ${ }^{2}$ And Christer Nilsson ${ }^{1,3}$ \\ ${ }^{1}$ Landscape Ecology Group, Department of Ecology and Environmental Science, Umeå University, \\ SE-901 87 Umeå, Sweden \\ ${ }^{2}$ Forest Biodiversity Group, Department of Ecology and Environmental Science, Umeå University, \\ SE-901 87 Umeå, Sweden \\ ${ }^{3}$ Department of Natural and Environmental Sciences, Mid Sweden University, SE-871 88 Härnösand, Sweden
}

\begin{abstract}
Buffer strips have recently become the main management practice for reducing logging impact on stream habitats in boreal and temperate regions. The habitat value of buffer strips, however, has not received much attention, although riparian forests belong to the systems with the highest biodiversity in these regions. We used plants as indicators of the ability of buffer strips to maintain an environment similar to intact riparian forests in a boreal forest landscape in northern Sweden. We measured the growth of three common bryophyte species (Hylocomiastrum umbratum, Calypogeia integristipula, and Tritomaria quinquedentata) transplanted to riparian habitat close to a stream in clear-cut logged sites, 10-15 m wide buffer strips on each side of the stream, and intact (reference) sites. Each of the three site categories included six wet and six moist-mesic sites and the experiment was followed over three months in 1999.

The species remained vital in the reference sites and grew substantially during the 3mo-long experiment, but in the logged sites almost no growth was registered, and many shoots died (except for T. quinquedentata). The pattern was consistent irrespective of the ground moisture class. The performance of bryophytes in the moist-mesic buffer strips was almost as bad as in the logged sites, whereas in the wet buffer strips it was either intermediate between that in logged and reference sites ( $H$. umbratum) or very similar to that in reference sites (C. integristipula and $T$. quinquedentata). The edge effect has previously been shown to vary depending on edge orientation, edge physiognomy, and weather conditions. We found that ground moisture can be of major importance as well. Although many buffer strips function better than no strips, 20-30 m wide strips (with a stream in the middle) through a logged area consist entirely of edge habitat. Increasing the buffer width and avoiding clear-cut logging on both sides of a watercourse would be the first steps to take for improving biodiversity conservation in riparian habitats. Our results also show that bryophytes are good indicators of habitat quality and efficient tools for assessing the ecological function of buffer strips.
\end{abstract}

Key words: biodiversity; boreal forests; bryophyte; buffer strips; edge effects; forestry; habitat quality; hepatic; moss; phytometer; Sweden.

\section{INTRODUCTION}

Riparian forests are ecotones in the landscape and encompass distinct gradients of environmental factors as well as ecological processes (Gregory et al. 1991, Naiman and Décamps 1997). Microclimatic variables such as light, temperature, and moisture differ between upland and riparian forests (Gregory et al. 1991) and influence the distribution of many species at the landscape level (Chen et al. 1999). Riparian forests have different communities of vascular plants (Gregory et al. 1991), bryophytes (Jonsson 1997), and birds and mammals (references in Naiman and Décamps 1997) compared to adjacent upland forests. The riparian community is usually disproportionately species rich compared to the uplands, and is considered a key habitat

Manuscript received 18 December 2000; revised 19 July 2001; accepted 24 August 2001.

${ }^{4}$ E-mail: kristoffer.hylander@eg.umu.se for biodiversity at the landscape level (Naiman et al. 1993, Naiman and Décamps 1997). Riparian ecosystems are interspersed throughout the landscape (Forman 1995), and their connectivity enhances dispersal of organisms (e.g., Nilsson et al. 1993, Machtans et al. 1996). Therefore, when attempting to combine wood production and biodiversity conservation an initial priority would be to not fragment the watercourse network across landscapes (Törnquist 1996, Gustafsson and Hansson 1997, Fries et al. 1998).

Leaving riparian buffer strips is a widely used management practice to reduce the impact of logging on stream habitats (Jorgensen et al. 2000). The focus has traditionally been on the aquatic biota (Swanson and Franklin 1992), and streams with fish have yielded most attention (Dupuis and Steventon 1999). Buffer strips are effective in reducing sediment and nutrient loads and for maintaining low water temperatures in streams in forest ecosystems (Clinnick 1985, Castelle et al. 
1994, Clausen et al. 2000). The width of an effective buffer (a buffer in this case is defined as the distance between the edge of the watercourse and the logged area) may vary (Castelle et al. 1994). For example, among small mammals and birds, different species have different preferences for buffer width (Darveau et al. 2001). Several studies from boreal and temperate regions have, however, shown that buffers around 30 $\mathrm{m}$ wide can be sufficient to minimize many negative effects of logging on the stream habitat (Hansmann and Phinney 1973, Newbold et al. 1980, Murphy et al. 1986, Holopainen and Huttunen 1992, Davies and Nelson 1994).

So far, the effectiveness of buffer strips in protecting the biodiversity of terrestrial organisms in riparian forests has received very little attention (Castelle et al. 1994). However, studies on bird assemblages show that bird densities are often higher in buffer strips than in comparable unlogged areas, but forest-dependent bird species are less abundant (Darveau et al. 1995, 1997, Hagar 1999, Meiklejohn and Hughes 1999, Pearson and Manuwal 2001). In a boreal forest landscape in Canada $60 \mathrm{~m}$ wide strips were required for forest-dependent birds (Darveau et al. 1995). The development of the vegetation in buffer strips is little explored. Hibbs and Giordano (1996) studied the vegetation of riparian red alder (Alnus rubra Bong.) forests that were converted to 5-40 m wide buffer strips. They found no effects on either overstory or understory composition except that one shrub species increased in abundance. Managers of riparian areas may benefit from the many general studies of edge effects (e.g., Chen et al. 1992, 1995, Murcia 1995). The specific characteristics of riparian zones, however, are that they are natural edges (or ecotones) (Naiman and Décamps 1997), and that riparian buffer strips have an edge toward both water and uplands.

The implementation rate of buffer strip management in forestry differs between countries, and policies and legislation differ among regions (Bergqvist 1999). In the United States, Canada, Australia, and New Zealand buffer strips have been widely used since the 1960 s (Brazier and Brown 1973, Clinnick 1985). In Sweden the practice is quite new and in an evaluation of the rate of environmental protection in the forest landscape during 1981-1985, Eckerberg (1988) found intact buffer strips along only $25 \%$ of the watercourses in logged areas. In the Nordic countries many new management practices for fauna and flora have been introduced during the last decade (Fries et al. 1997), and the economic and environmental aspects have been given equal status in the new Swedish Forestry Act (Anonymous 1994). As a consequence, forest companies have designed general guidelines for biodiversity, including buffer strip management (SCA 1998, Karlsson et al. 1999, MoDo 1999). Market pressure and certification of forest products have also greatly impacted management practices. Still, however, logging operations may result in the complete removal of riparian forests (K. Hylander, personal observation).

Our study was designed to evaluate the extent to which the $10-15 \mathrm{~m}$ wide riparian buffers commonly used in northern Sweden can maintain an environment suitable for forest understory organisms. Chen et al. (1999) suggested that measurements of the microclimate could be used to monitor and compare the effects of different management practices. Dong et al. (1998) also pointed out that process-based research on organisms is needed to confirm the pattern from the microclimate measurements. Since microclimatic parameters such as temperature, air humidity, wind speed, and light covary from the edge to the interior of a forest (Young and Mitchell 1994, Cadenasso et al. 1997), the use of a phytometer is a way to evaluate the combined microclimatic edge effect. Species relying on humid air during their lifetime would be especially sensitive to changes in microclimate and could serve as such monitors (Dong et al. 1998).

We used bryophyte growth as an indicator of differences in growing conditions (most probably related to microclimate) between sites with different forestry treatment. Bryophytes are poikilohydric, i.e., they lack effective mechanisms for regulating uptake and loss of water (Proctor 1990). The time in a hydrated condition is therefore crucial for growth (Busby et al. 1978, Callaghan et al. 1978). These characteristics and the fact that riparian forests have well-developed and speciesrich bryophyte communities (Jonsson 1997, Pharo and Beattie 1997), suggest that bryophytes are good indicators of changes caused by different forestry practices along streams.

\section{Methods \\ Study area}

The study was conducted in the boreal zone (Ahti et al. 1968) in the province of Västerbotten, northern Sweden (Fig. 1). The area is mainly covered with forest of Scots pine (Pinus sylvestris L.) and Norway spruce (Picea abies L. Karst.), with scattered birches (Betula pubescens Ehrh. and Betula pendula Roth) and aspen (Populus tremula L.). Along lakeshores and riverbanks gray alder (Alnus incana L. [Moench]) is common. The landscape is intensively managed for wood production and has been so for $\sim 150$ years (Wastenson and Nilsson 1990). The average annual growth rate of timber is 4$5 \mathrm{~m}^{3} / \mathrm{ha}$. The growing season is $\sim 150$ days (Raab and Vedin 1995). The mean annual precipitation is $\sim 750$ $\mathrm{mm}$ and the average monthly precipitation for July, August, and September is 70, 81, and $64 \mathrm{~mm}$, respectively. The mean temperatures for these months are $14.4^{\circ} \mathrm{C}, 12.4^{\circ} \mathrm{C}$, and $7.3^{\circ} \mathrm{C}$ (mean of $30 \mathrm{yr}$ ).

\section{Study species}

We selected three bryophyte species (Hylocomiastrum umbratum [Hedw.] Fleisch., Calypogeia integris- 


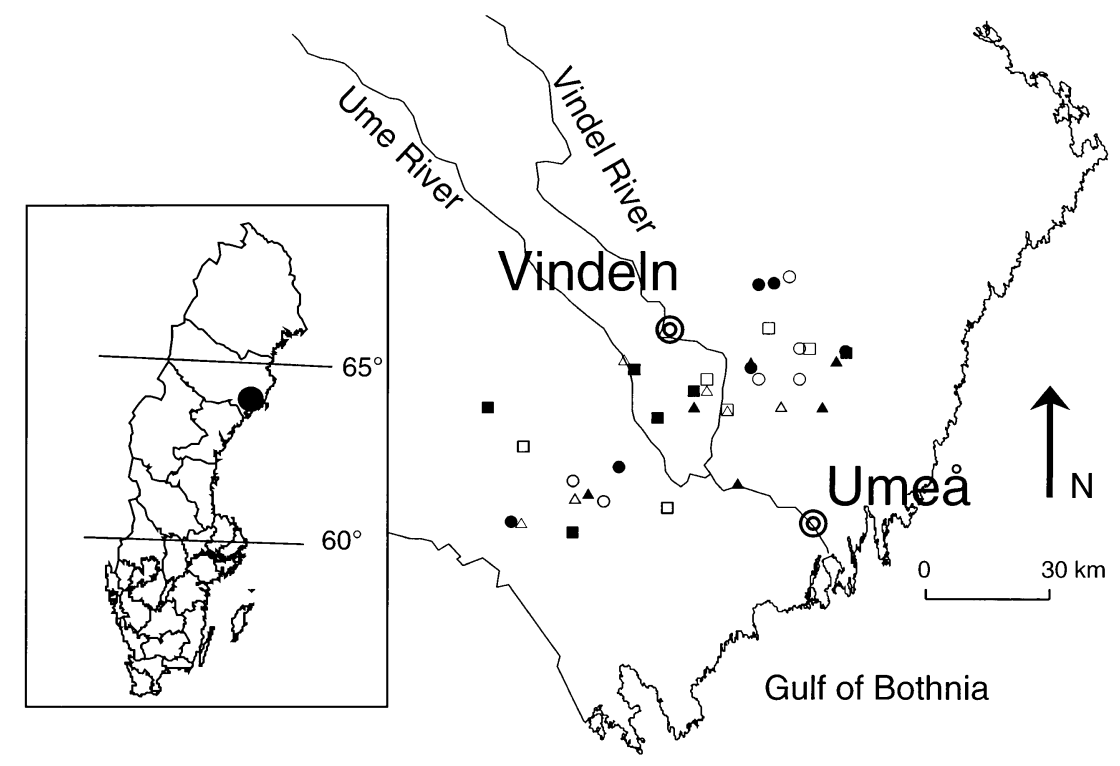

FIG. 1. Location of the study sites in northern Sweden. Symbol definitions are: triangle, clear-cut; square, buffer strip; circle, reference (interior forest). Filled symbols indicate wet areas, and unfilled symbols indicate moist-mesic ones.

tipula Steph., and Tritomaria quinquedentata [Huds.] Buch.), which all grow naturally in riparian forests and other shaded habitats (Hallingbäck 1996). H. umbratum is a large pleurocarpous understory moss, which also grows on boulders and logs. The growth of $H$. umbratum is generally easy to follow as it produces a new growth segment every year. $C$. integristipula is a leafy hepatic that grows closely to substrates such as humusrich soil, woody debris, tree bases or crevices below stumps and tree roots, while $T$. quinquedentata is a leafy hepatic that grows among other bryophytes on the ground in moist sites and on shaded boulders and rocky outcrops.

\section{Experimental design}

We compiled a list of both mature and newly logged forest stands intersected by streams (mostly first order). We then identified three categories of forestry treatment along streams (clear-cut logged sites, logged sites with a 10-15 m wide buffer strip left at each side along the stream, and mature forest sites) and selected 12 stands from each class. The sites were stratified according to ground moisture cover so that half of the sites in each group (six sites) had a large proportion (10-90\%) of wet ground in an area of $20 \times 20 \mathrm{~m}$ with the stream in the middle, and half of the sites had moist or mesic ground ( $<10 \%$ wet ground). Wet ground is defined as ground with the water table in the surface or just below for most of the year (Hägglund and Lundmark 1981). In the wet class the pots with bryophytes (see below) were located in places with a peat moss (Sphagnum spp.) cover. Altogether, the experiment included six treatments replicated six times.

At each site, two stations with bryophytes were established $2 \mathrm{~m}$ from each side of the stream. At each station two pots with $H$. umbratum were placed on a board to prevent groundwater contact. Another two pots with $H$. umbratum, two pots with $C$. integristipula, and one pot with $T$. quinquedentata were dug into the ground. Altogether eight pots of $H$. umbratum, four pots of $C$. integristipula, and two pots of T. quinquedentata were located at each of the 36 sites. The lower number of replicates at pot level and the restricted design of the experimental setup for $C$. integristipula and T. quinquedentata were due to limited availability of material for transplantation.

\section{Response variables for the bryophytes}

Material of $H$. umbratum from the Umeå region was put on slightly fertilized peat (soil improvement medium for gardens) in 288 black pots with a diameter of 11-12 cm. In every pot, five shoots were marked with small plastic rings (diameter $5 \mathrm{~mm}$ ) of five different colors, and the initial length of the youngest small segments was measured. $C$. integristipula and $T$. quinquedentata, also from the Umeå region, were planted in small pieces $(\sim 30 \times 30 \mathrm{~mm})$ on the same substrate in the center of each pot $(7.7 \times 7.7 \mathrm{~cm})$. Smaller pots were used as the species are smaller and we had limited material for transplantation. Every pot was photographed with a digital camera and bryophyte percent cover was calculated with the UTHSCSA image tool (Wilcox et al. 1995-1996). The pots were installed between 22 June and 2 July 1999 and revisited three months later (21-28 September). When revisited, the lengths of the marked segments were measured on $H$. umbratum, and the growth (in millimeters) was calculated. In some cases the marked segment was shorter after the treatment because it had died, hence a negative "growth." Photographs were taken of every pot of $C$. 
TABLE 1. Percent cover of different ground moisture categories in an area of $20 \times 20 \mathrm{~m}$ around the experimental site at wet and moist-mesic clear-cut, buffer strip, and reference sites.

\begin{tabular}{|c|c|c|c|c|c|c|}
\hline \multirow[b]{2}{*}{ Variable } & \multicolumn{2}{|c|}{ Clear-cut } & \multicolumn{2}{|c|}{ Buffer strip } & \multicolumn{2}{|c|}{ Reference } \\
\hline & Wet & Moist-mesic & Wet & Moist-mesic & Wet & Moist-mesic \\
\hline Wet ground & $53.3 \pm 32.0$ & $1.67 \pm 2.58$ & $45.0 \pm 28.8$ & $6.67 \pm 5.17$ & $51.7 \pm 21.4$ & $4.17 \pm 4.92$ \\
\hline Moist ground & $45.0 \pm 31.5$ & $61.7 \pm 31.7$ & $45.0 \pm 21.7$ & $75.0 \pm 18.7$ & $36.7 \pm 16.3$ & $42.5 \pm 20.9$ \\
\hline Mesic ground & $1.67 \pm 4.08$ & $36.7 \pm 32.7$ & $10.0 \pm 15.5$ & $18.3 \pm 19.4$ & $11.7 \pm 9.8$ & $53.3 \pm 23.4$ \\
\hline
\end{tabular}

Note: For each variable the mean value in percent $\pm 1 \mathrm{SD}$ is given $(N=6)$.

integristipula and T. quinquedentata and the percent cover was recalculated. The relative growth (change/ original area) of $C$. integristipula and T. quinquedentata was calculated for each pot. In September also the vitality of the bryophyte in each pot was estimated on a scale with seven classes: (1) dead; (2) some leaves green; (3) some shoots green; (4) half of the shoots alive; (5) alive but affected; (6) most of the shoots vigorous; and (7) the entire plant fresh and growing.

\section{Estimated environmental variables}

At each site we measured environmental variables in an area of $20 \times 20 \mathrm{~m}$ surrounding the plot stations. We measured the basal area of trees using a relascope (Skogsmateriel Nordforest AB, Strömsund, Sweden) and counted the number of trees $>5 \mathrm{~cm}$ diameter at breast height and the number of shrubs. The height of an average-sized tree was used as a measure of forest height. The proportions of wet, moist, and mesic ground were estimated according to definitions in Hägglund and Lundmark (1981) as well as percent cover of the vascular plant understory. The width of the stream and the mean buffer width were also measured. The aspect of the stream was divided into two variables; northward aspect was calculated using the formula sin $\alpha$, where $\alpha$ is the angle in radians, and eastward aspect was calculated with $\cos \alpha$. The variables can vary from -1 to +1 , with north and east at the positive side of the axes. The slope of the stream and the lateral slopes were measured using a rod and a level. The slope of the stream was measured along a $20-\mathrm{m}$ stretch and the lateral slopes were measured on both sides from the center of the stream to $20 \mathrm{~m}$ from it, divided into $5-\mathrm{m}$ segments. Means were calculated for 0-5, 5-10, 10$15,15-20$, and $0-20 \mathrm{~m}$. The distance to mature forest on both sides of the stream was roughly estimated for the logged and buffer strip sites. Site altitude was noted from maps.

\section{Statistical analyses}

The growth of H. umbratum was analyzed using a mixed ANOVA model with the random variable "site" nested within the interaction of treatment and ground moisture. The term vertical position (on a board or dug into the ground) was orthogonal as it was included in all sites. The five measurements in each pot were pooled to meet the presumptions of equal variances. The ANOVA model for the relative growth of $C$. in- tegristipula was similar except that the term position was lacking. For $T$. quinquedentata the mean of the relative growth for the two pots at every site was used as the replicate level to meet the presumptions of equal variance, thus not permitting analysis of the variance component for site. All statistical calculations were performed with the SPSS software package (Norušis 1993). The vitality for all the species was analyzed with nonparametric methods as the data was discrete. Multiple regression models (stepwise selection) and correlations were applied to test if the differences in growth in the buffer strip class could be understood from differences in the measured environmental variables. Eleven of the 288 pots with H. umbratum from six sites were excluded as they had fallen or the moss had disappeared during the experiment. For the same reason 5 out of 144 of the pots of $C$. integristipula in four sites and 3 out of 72 of the pots of $T$. quinquedentata in three sites were excluded.

\section{REsults \\ Weather}

The three months (July-September 1999) of the experiment were warm and dry compared to the average situation. At Vindeln weather station the temperature in July was $1.2^{\circ} \mathrm{C}$ above average, in August $0.3^{\circ} \mathrm{C}$ below average, and in September $3.2^{\circ} \mathrm{C}$ above average. The precipitation amounted to 38,48 , and $14 \mathrm{~mm}$ for the same months, which is $14-60 \%$ of normal precipitation.

\section{Environmental variables}

The wet sites turned out to have a mean percent cover of wet ground of $\sim 50 \%$ at both logged, buffer strip, and reference sites (Table 1), and were in most cases flatter than the moist-mesic sites both along and across the streams (Table 2). The logged areas were almost treeless whereas the buffer strips had a slightly thinner forest cover than the reference sites (basal area, number of trees, and average tree height) (Table 2). The understory percent cover was denser in the logged and buffer strip sites than in the reference sites. The lateral slope (mean of both sides) was slightly steeper near the stream in the reference sites than in the buffer strip sites, even if the total vertical distance was similar over $20 \mathrm{~m}$ for both of the treatments. This is also a likely reason why there was slightly more mesic ground and less moist ground in the reference sites. 
TABLE 2. Environmental variables at wet and moist-mesic clear-cut, buffer strip, and reference sites.

\begin{tabular}{|c|c|c|c|c|c|c|}
\hline \multirow[b]{2}{*}{ Variable } & \multicolumn{2}{|c|}{ Clear-cut } & \multicolumn{2}{|c|}{ Buffer strip } & \multicolumn{2}{|c|}{ Reference } \\
\hline & Wet & Moist-mesic & Wet & Moist-mesic & Wet & Moist-mesic \\
\hline \multicolumn{7}{|l|}{ Basal area $\left(\mathrm{m}^{2}\right)$} \\
\hline Total basal area of trees & $2.7 \pm 1.7$ & $0.58 \pm 0.58$ & $17.0 \pm 2.5$ & $22.5 \pm 4.3$ & $21.2 \pm 3.2$ & $24.2 \pm 4.0$ \\
\hline Picea abies & $0.33 \pm 0.61$ & $0.25 \pm 0.61$ & $12.9 \pm 3.7$ & $17.0 \pm 8.0$ & $15.7 \pm 5.0$ & $18.6 \pm 8.2$ \\
\hline Pinus sylvestris & $0.50 \pm 1.00$ & 0 & $0.9 \pm 1.5$ & $1.5 \pm 1.5$ & $0.83 \pm 2.0$ & $1.6 \pm 1.9$ \\
\hline Deciduous trees & $1.8 \pm 1.4$ & $0.33 \pm 0.40$ & $3.2 \pm 3.1$ & $4.0 \pm 3.5$ & $4.7 \pm 2.6$ & $4.1 \pm 4.4$ \\
\hline \multicolumn{7}{|l|}{ Number of trees $(\mathrm{dbh}>5 \mathrm{~cm})$} \\
\hline Total number of trees & $10.7 \pm 6.0$ & $1.2 \pm 2.4$ & $41.2 \pm 14.3$ & $37.5 \pm 12.6$ & $63.3 \pm 19.3$ & $49.8 \pm 19.7$ \\
\hline Picea abies & $5.3 \pm 2.5$ & $0.33 \pm 0.81$ & $27.8 \pm 10.2$ & $28.0 \pm 10.9$ & $40.3 \pm 10.2$ & $36.8 \pm 8.7$ \\
\hline Pinus sylvestris & $0.33 \pm 0.82$ & 0 & $0.33 \pm 0.82$ & $1.2 \pm 1.2$ & $1.8 \pm 4.5$ & $2.5 \pm 2.5$ \\
\hline Deciduous trees & $5.0 \pm 4.8$ & $0.83 \pm 1.6$ & $13.0 \pm 7.8$ & $8.3 \pm 6.6$ & $21.2 \pm 16.4$ & $10.5 \pm 11.3$ \\
\hline \multicolumn{7}{|l|}{ Slopes $(\%)$} \\
\hline Along stream $20 \mathrm{~m}$ & $0.97 \pm 0.86$ & $4.8 \pm 2.3$ & $2.3 \pm 1.7$ & $1.9 \pm 1.2$ & $1.6 \pm 1.8$ & $3.1 \pm 1.2$ \\
\hline Lateral to stream $0-20 \mathrm{~m}$ & $5.5 \pm 5.3$ & $11.1 \pm 2.9$ & $6.4 \pm 3.3$ & $8.7 \pm 2.4$ & $7.3 \pm 7.5$ & $8.7 \pm 7.2$ \\
\hline Segment $0-5 \mathrm{~m}$ & $5.9 \pm 3.1$ & $10.5 \pm 2.8$ & $6.2 \pm 3.5$ & $11.6 \pm 6.7$ & $7.3 \pm 4.5$ & $14.2 \pm 8.0$ \\
\hline Segment $5-10 \mathrm{~m}$ & $4.1 \pm 5.7$ & $10.6 \pm 7.7$ & $5.1 \pm 4.1$ & $5.9 \pm 10.6$ & $8.7 \pm 10.4$ & $10.9 \pm 7.1$ \\
\hline Segment $10-15 \mathrm{~m}$ & $5.6 \pm 8.2$ & $12.2 \pm 9.6$ & $7.1 \pm 4.3$ & $8.3 \pm 4.4$ & $9.5 \pm 14.7$ & $6.5 \pm 11.4$ \\
\hline Segment $15-20 \mathrm{~m}$ & $6.5 \pm 9.8$ & $11.2 \pm 7.9$ & $7.1 \pm 4.4$ & $9.0 \pm 10.2$ & $3.8 \pm 5.8$ & $3.2 \pm 17.6$ \\
\hline Width of buffer strip (m) & $\cdots$ & $\ldots$ & $13.1 \pm 3.4$ & $11.9 \pm 3.6$ & $\ldots$ & $\ldots$ \\
\hline Tree of average height (m) & $\ldots$ & $\ldots$ & $13.7 \pm 7.2$ & $20.0 \pm 4.5$ & $19.7 \pm 3.5$ & $23.2 \pm 3.2$ \\
\hline Number of shrubs & $82.0 \pm 55.7$ & $71.8 \pm 46.2$ & $81.7 \pm 41.7$ & $52.8 \pm 33.9$ & $60.7 \pm 25.8$ & $78.7 \pm 30.9$ \\
\hline Understory cover $(\%)$ & $75.8 \pm 16.3$ & $94.2 \pm 7.4$ & $76.7 \pm 14.7$ & $89.2 \pm 9.7$ & $49.2 \pm 22.5$ & $73.3 \pm 24.2$ \\
\hline Stream width $(\mathrm{m})$ & $0.58 \pm 0.46$ & $0.88 \pm 0.82$ & $0.49 \pm 0.31$ & $1.0 \pm 0.27$ & $1.03 \pm 0.61$ & $1.02 \pm 0.39$ \\
\hline \multicolumn{7}{|l|}{ Stream direction } \\
\hline East $\dagger$ & $-0.04 \pm 0.76$ & $0.10 \pm 0.77$ & $-0.07 \pm 0.47$ & $0.25 \pm 0.80$ & $0.28 \pm 0.48$ & $0.18 \pm 0.77$ \\
\hline North $\dagger$ & $-0.56 \pm 0.48$ & $0.08 \pm 0.77$ & $-0.08 \pm 0.98$ & $-0.17 \pm 0.70$ & $-0.14 \pm 0.92$ & $0.02 \pm 0.75$ \\
\hline \multicolumn{7}{|l|}{ Width of open area (m) } \\
\hline Left of stream & $124 \pm 119$ & $137 \pm 109$ & $167 \pm 81$ & $250 \pm 184$ & $\ldots$ & $\ldots$ \\
\hline Right of stream & $240 \pm 200$ & $258 \pm 139$ & $208 \pm 102$ & $133 \pm 68$ & $\cdots$ & $\cdots$ \\
\hline Altitude (m a.s.1.) & $141 \pm 63$ & $152 \pm 35$ & $179 \pm 42$ & $191 \pm 46$ & $195 \pm 57$ & $182 \pm 46$ \\
\hline
\end{tabular}

Note: For each variable the mean value $\pm 1 \mathrm{SD}$ is given $(N=6)$.

$\dagger$ For the calculations of stream direction see Methods section.

The only environmental variable that was correlated with the growth of $H$. umbratum in the buffer strips was the proportion of mesic ground $(r=-0.58, P=$ 0.0048). A stepwise multiple regression procedure revealed five significant models for growth of $H$. umbratum in buffer strips. The fifth model with the highest $R^{2}$ value (0.98) included all the five environmental variables in the following order (positive or negative impact on growth in brackets): proportion of mesic ground $(-)$, proportion of understory percent cover $(-)$, width of open area right of stream $(-)$, number of deciduous trees $(+)$, and basal area of pine $(-)$. The width of the buffer (interval 8-18 m) did thus not significantly correlate with the growth or add significantly to the regression model. No environmental variable was correlated with the relative growth of $C$. integristipula or T. quinquedentata in buffer strips.

\section{Forestry treatment and soil moisture}

All three species grew less in the logged than in the reference sites $(P<0.05)$. The mean growth of $H$. umbratum varied from $2.5 \mathrm{~mm}$ in wet, logged areas to $20.2 \mathrm{~mm}$ in wet reference areas (when pots on board and into the ground were pooled) (Fig. 2a). The mean relative growth of $C$. integristipula varied from -0.49 in the moist-mesic logged areas to 0.67 in the wet reference sites (Fig. 2c), and the mean relative growth in $T$. quinquedentata varied from -0.29 in the wet, logged areas to 0.40 in the wet reference sites (Fig. 2d). The response in the buffer strips, however, varied depending on ground moisture and species. In one case (T. quinquedentata) the growth in the wet buffer strip site was higher than the growth in the wet reference site.

For $H$. umbratum the mean growth for the buffer strip sites differed significantly $(P<0.001)$ from the means for both the logged sites and the reference sites (Tukey's test). However, H. umbratum grew only slightly better in the moist-mesic buffer strip sites than in the moist-mesic logged sites (Fig. 2a). The moss grew better in the wet sites compared to the moistmesic sites $(P=0.015)$, but the significant interaction term indicates that the pattern was not consistent (Table 3 ). In fact, the growth was slightly higher in the moistmesic logged sites than in the wet, logged sites (Fig. 2a).

For $C$. integristipula the mean growth in the buffer strips was significantly different $(P<0.01)$ from both 

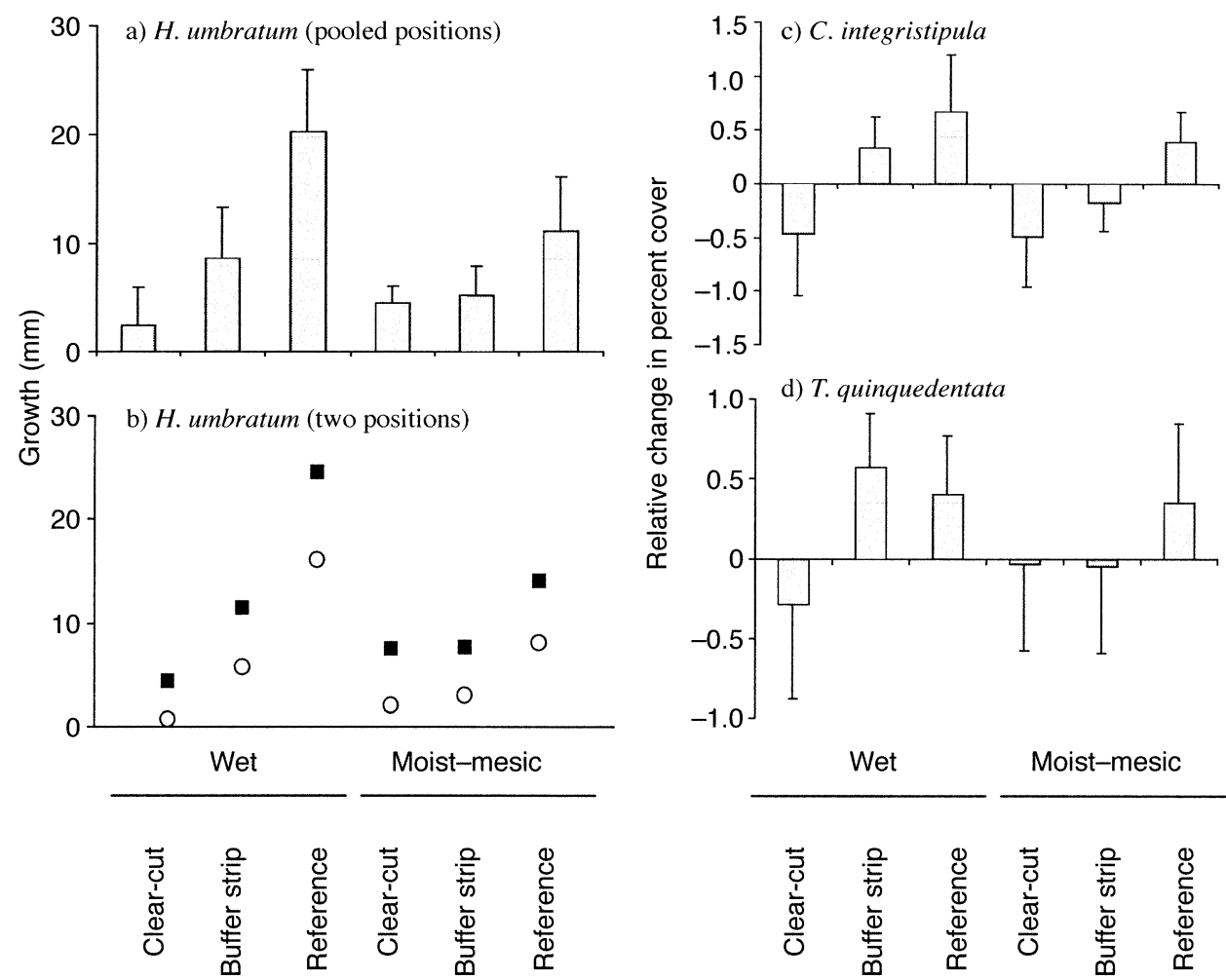

FIG. 2. Growth or relative growth of (a, b) Hylocomiastrum umbratum, (c) Calypogeia integristipula, and (d) Tritomaria quinquedentata in clear-cuts, buffer strips, and references (interior forests) with two different ground moisture classes, and for (b) two different positions (on boards on the ground surface or dug into the ground). Bars indicate \pm 1 SD from the mean value $(N=6)$. For statistical interpretation see Table 3 .

logged and reference sites (Tukey's test). Forestry treatment was the only significant variable explaining the variation in response of $C$. integristipula (Table 3 ). As for $H$. umbratum, $C$. integristipula in references and buffer strips grew better in the wet sites than in the moist-mesic sites (Fig. 2c). In fact, the growth of $C$. integristipula in the wet buffer strips was significantly higher than in the moist-mesic ones $(P=0.007$, Student's $t$ test).

Forestry treatment was the only significant variable explaining the variation in response of T. quinquedentata (Table 3). Only the difference between the logged sites and the reference sites was significant $(P=0.035$, Tukey's test). The pattern of response, however, was

TABLE 3. Analysis of variance of growth of Hylocomiastrum umbratum and relative growth of Calypogeia integristipula and Tritomaria quinquedentata.

\begin{tabular}{|c|c|c|c|c|c|c|}
\hline \multirow[b]{2}{*}{ Source of variation } & \multicolumn{2}{|c|}{$\begin{array}{l}\text { H. umbratum } \\
(N=279)\end{array}$} & \multicolumn{2}{|c|}{$\begin{array}{l}\text { C. integristipula } \\
(N=138)\end{array}$} & \multicolumn{2}{|c|}{$\begin{array}{c}\text { T. quinquedentata } \\
(N=35)\end{array}$} \\
\hline & $F$ & $P$ & $F$ & $P$ & $F$ & $P$ \\
\hline Vertical position & 73.59 & $<0.001$ & & & & \\
\hline Treatment & 26.55 & $<0.001$ & 18.53 & $<0.001$ & 3.88 & 0.032 \\
\hline Ground moisture & 6.74 & 0.015 & 3.97 & 0.056 & 0.69 & 0.41 \\
\hline Vertical position $\times$ treatment & 1.49 & 0.24 & & & & \\
\hline Vertical position $\times$ ground moisture & 0.41 & 0.52 & & & & \\
\hline Treatment $\times$ ground moisture & 5.43 & 0.010 & 0.91 & 0.41 & 2.42 & 0.10 \\
\hline Treatment $\times$ ground moisture $\times$ vertical position & 1.06 & 0.36 & & & & \\
\hline Site(treatment $\times$ ground moisture) & 4.66 & $<0.001$ & 1.39 & 0.11 & & \\
\hline Site (treatment $\times$ ground moisture $) \times$ vertical position & 1.04 & 0.41 & & & & \\
\hline
\end{tabular}

Notes: The $F$ values are weighted with respect to nonsignificant interactions. The statistical model evaluated is for $H$. umbratum, $y=\alpha+\beta+\gamma+\alpha \beta+\alpha \gamma+\beta \gamma+\alpha \beta \gamma+\delta(\beta \gamma)+\delta(\beta \gamma) \alpha+\varepsilon$; for C. integristipula, $y=\beta+\gamma+\beta \gamma+\delta(\beta \gamma)$ $+\varepsilon$; and for T. quinquedentata, $y=\beta+\gamma+\beta \gamma+\varepsilon$. The following terms are evaluated: $\alpha=$ vertical position (on a board or dug into the ground); $\beta=$ treatment (clear-cut, buffer strip, and reference); $\gamma=$ ground moisture (wet or moist-mesic) and $\delta=$ site (36 sites). The variables within which a term is nested are set in parentheses. 


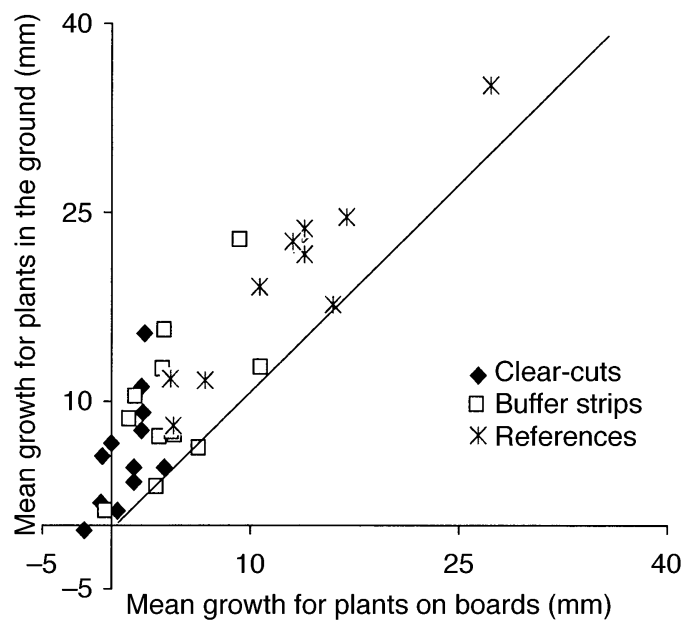

FIG. 3. Growth of Hylocomiastrum umbratum in pots placed in two different positions. Data are mean values $(N$ $=4)$. There was a strong correlation between the growth in the two positions $(r=0.90)$, but plants in the ground grew better. The regression line indicates a situation with equal growth in the two positions.

similar to that of the other two species except that $T$. quinquedentata grew well in both the wet reference sites and in the wet buffer strip sites (Fig. 2d). The response in the buffer strips was much higher in the wet than in the moist-mesic sites $(P=0.045$; Student's $t$ test), and the response in the moist-mesic class was similar for buffer strip and logged sites.

\section{On board or into ground}

Besides forestry treatment, ground moisture, and the interaction between the two, the vertical position (on board or into ground) and the site contributed significantly to the response in growth of $H$. umbratum (Table $3)$. In almost all of the sites the shoots grew better in the pots dug into the ground than in the pots on the board (Fig. 3). However, the mean growth was strongly correlated ( $r=0.90$ ) between the pots in the two positions indicating a strong "site effect." There were no significant interactions between position and the other variables and $H$. umbratum responded in the same way to treatment and ground moisture regardless of whether the pot was standing above the ground or dug into it (Fig. 2b). The treatment component contained most of the variance followed by vertical position and ground moisture.

\section{Vitality}

The vitality of all species differed between treatments $(P<0.003$, Kruskal-Wallis test). For H. umbratum and $C$. integristipula the shoots were on average vigorous in the reference sites but had only some green shoots remaining in the logged sites (Table 4). The vitality in the buffer strip sites was intermediate for $H$. umbratum and $C$. integristipula, but higher in the wet than in the moist-mesic sites $(H$. umbratum $P=0.03$,
C. integristipula $P=0.007$, Mann-Whitney $U$ test). The proportion of pots with dead $C$. integristipula was $48 \%$ for logged sites, $10 \%$ for buffer strips, and $2 \%$ for references. The mean for logged sites differed significantly from the others $(P<0.01$, Mann-Whitney $U$ test). For $T$. quinquedentata the vitality was only slightly reduced in the logged sites and was equal between the buffer strip and reference sites (Table 4).

\section{DISCUSSION}

Our study shows that the growth of forest bryophytes is reduced in both clear-cut stream forests and in narrow buffer strips along small streams. It is well known that there are large microclimatic differences between clearcut areas and intact forests but also climatic gradients through forest edges (e.g., Cadenasso et al. 1997) and buffer strips (Brosofske et al. 1997). We have taken advantage of the poikilohydric quality of bryophytes, chosen species naturally growing under a forest canopy, and in the experimental setup emphasized the influence of the local environment ("microclimate") by using pots with and without ground (and groundwater) contact. The most likely explanation for the reduced growth and vitality of $H$. umbratum growing without ground contact in clear-cut habitats and narrow buffer strips (Fig. 2b) is that the local environment has been altered by the logging. The same explanation probably holds true also for bryophytes dug into the ground because the pattern of response for all species is very similar to that of $H$. umbratum without ground contact (Fig. 2b-d). Due to the poikilohydric nature of the study species, the similar and artificial culture conditions, and the lack of competition or herbivory, we even find it difficult to suggest alternative hypotheses for the observed pattern.

Although buffer strips did not have the same qualities as intact forest (reference) sites, the buffer strips still had a buffering effect as all the studied species had higher vitality in the buffer strips than in the clearcut areas (Table 4). Many factors influence the effec-

TABLE 4. Vitality of three bryophyte species (Hylocomiastrum umbratum, Calypogeia integristipula, and Tritomaria quinquedentata) after being exposed to different forestry treatment sites for three months (mean $\pm 1 \mathrm{SD}$ ).

\begin{tabular}{|c|c|c|c|}
\hline Site & H. umbratum & $\begin{array}{l}\text { C. integristi- } \\
\text { pula }\end{array}$ & $\begin{array}{c}\text { quinqueden } \\
\text { tata }\end{array}$ \\
\hline \multicolumn{4}{|l|}{ Wet sites } \\
\hline Clear-cut & $3.2 \pm 1.45$ & 2.41 & $5.1 \pm 1.56$ \\
\hline Buffer strip & $5.3 \pm 1.42$ & $6.4 \pm 1.50$ & $6.8 \pm 0.58$ \\
\hline Reference & $6.7 \pm 0.52$ & $7.0 \pm 0$ & $6.2 \pm 1.93$ \\
\hline \multicolumn{4}{|c|}{ Moist-mesic sites } \\
\hline Clear-cut & $3.4 \pm 1.30$ & $3.4 \pm 2.54$ & $5.7 \pm 1.56$ \\
\hline Buffer strip & $4.7 \pm 1.45$ & $4.8 \pm 2.32$ & $6.2 \pm 1.61$ \\
\hline Reference & $5.9 \pm 1.05$ & $6.5 \pm 1.56$ & $6.8 \pm 0.60$ \\
\hline
\end{tabular}

Notes: The vitality classes are: (1) dead, (2) some leaves green, (3) some shoots green, (4) half of the shoots alive, (5) alive but affected, (6) most of the shoots vigorous, and (7) the entire plant fresh and growing. For statistical comparisons see Results: Vitality. 
tiveness of a buffer strip and it is not possible to generalize without knowing the importance and variation among those factors. In our study the differences between the two ground moisture classes were pronounced for all the species in the buffer strips. The multiple regression models (for $H$. umbratum) also confirm this since all of the contributing variables in fact reflected the stratification of the sites in the two soil moisture classes. We were not able to detect any influence of the width of the buffer strips on the growth or vitality of the species, suggesting that the used interval (8-18 $\mathrm{m}$ on one side of the stream) was too narrow to have a differentiating effect.

Several studies have shown a strong relationship between growth and time in wet condition for different bryophytes (Pitkin 1975, Vitt 1989, Proctor 1990). Given equal precipitation, the conditions for evaporation are essential for growth, and a shaded and moist environment can extend the wet time substantially (Busby et al. 1978). The light saturation point is relatively low in bryophytes, compared to many vascular plants, and is often exceeded during full sunlight (Proctor 1990). This means that growth, even in wet condition, may not be better in sunny than in more shaded habitats. Clausen (1964) showed that relative humidity and desiccation rate are crucial factors in determining whether many hepatics will maintain their ability to regain photosynthetic capacity when they become moistened. Also mosses that normally grow in shade are sensitive to long periods of drought at low relative humidity (Proctor 1990). This fact can explain why not only the growth but also the vitality of species were affected when the bryophytes were exposed in the logged and buffer strip sites.

The fact that shoots of $H$. umbratum grew better in the pots dug into the ground than in those on the boards in all but two sites, demonstrates the large difference in growing conditions that might occur within a short vertical distance $(\sim 10 \mathrm{~cm}$; Fig. $2 \mathrm{~b})$. The difference in moss growth between the two different positions was probably partly due to differences in air moisture. This is supported by the fact that mosses on the boards grew better in wet than in moist-mesic buffer strip sites (Fig. $2 b)$. The strong correlation $(r=0.90)$ between the growth of the moss on the boards and in the ground (Fig. 3) illustrates that every site has its own specific, environmental conditions for growth.

It is often the climatic extremes that determine the distribution patterns of species (see e.g., Crawford 1989). Because the experimental period was drier than normal, the results reflect what may be regarded as a critical period that would accentuate the difference between sites. Apparently the vitality of some bryophytes can be heavily affected within a few weeks after transplantation to an exposed site (Busby et al. 1978). If the experimental year had been very wet, the differences between sites would have been reduced and a longer experiment required.

\section{Conclusions and management implications}

Our results allow two general statements about narrow buffer strips (10-15 $\mathrm{m}$ on each side of a stream) in a boreal forest landscape. (1) Currently established buffer strips in coniferous forests can keep plant species alive, but are not wide enough to maintain natural growth conditions for riparian forest plants. (2) Plants naturally growing in both wet and moist riparian forests will encounter better conditions in wet than in moist buffer strips of equal width because edge effects are reduced in wet habitats.

The width of the riparian zone is determined by the local topography, and flat valley bottoms may have extensive areas of wet riparian ground. This fact has led Swedish forest companies to recommend that buffer strips along streams should be wider in wet than in mesic sites (SCA 1998, Karlsson et al. 1999, MoDo 1999). Even in mesic areas, however, the local environment differs between upland and riparian forests, and Brosofske et al. (1997) found that a gradient in microclimate extended up to $50 \mathrm{~m}$ from the stream. There are many reasons for leaving buffer strips along streams and the recommendations regarding their width and location vary (Clinnick 1985, Large and Petts 1994). If the goal is to conserve biodiversity confined to the riparian forest habitat, our results suggest that buffer strips should be wider than 10-15 m (on each side of the stream), at least along streams with moistmesic riparian forests. In a restricted plant conservation context, our results do not support the view of many forest companies (SCA 1998, MoDo 1999) that buffer strips should be widest on wet ground. In a general ecological respect, however, this recommendation may well be true and we have not addressed the needs of any species confined to wet riparian forests. To achieve a stream-influenced forest zone with interior conditions the buffer strips should extend outside this zone. It is therefore impossible, first to apply fixed buffer widths, and, second, to provide recommendations about any buffer width without knowing the width of the streaminfluenced forest zone in focus. More knowledge is needed about the width of the stream-influenced forest zone as a factor determining the distribution of species in the landscape and of the sensitivity of the organisms to edge effects. In cases when the riparian zone is wide the buffer strip probably must extend hundreds of meters from the stream to remove any single edge effect (Olsen 1995, Esseen and Renhorn 1998). Therefore, in a real-world design of buffer zones, realistic goals need to be set to balance the needs of nature conservation and commercial forestry. Managing forestry landscapes for ecological sustainability under these restrictions is an immense challenge.

\section{ACKNOWLEDGMENTS}

We thank MoDo, AssiDomän, and several small private forest owners for providing information about useful sites and permitting us to work there. The Local Board of Forestry 
(Skogsvårdsstyrelsen) and Anders Lidman at the Local Authority (Umeå kommun) were helpful in providing information about different forest sites. Niklas Rydén assisted in the fieldwork and Elisabet Carlborg helped with processing of primary data. Valuable support regarding the statistics was received from Kjell Leonardsson. Henrik Weibull introduced us to the marking method and provided material for that. Mats Dynesius gave much support during the study and Terry Hedderson, Kristin Palmqvist, and two anonymous reviewers provided valuable comments on the manuscript. The Swedish Meteorological and Hydrological Institute provided meteorological data for the Vindeln station. The Swedish Council for Forestry and Agricultural Research funded this work (to C. Nilsson).

\section{Literature Cited}

Ahti, T., L. Hämet-Ahti, and J. Jalas. 1968. Vegetation zones and their sections in northwestern Europe. Annales Botanici Fennici 5:169-211.

Anonymous. 1994. Skogsvårdslagen, Handbok. Swedish Forestry Board, Jönköping, Sweden.

Bergqvist, B. 1999. Påverkan och skyddszoner vid vattendrag i skogs- och jordbrukslandskapet: en litteraturöversikt. National Board of Fisheries, Göteborg, Sweden.

Brazier, J. R., and G. W. Brown. 1973. Buffer stream temperature control. Oregon State University, Corvallis, Oregon, USA.

Brosofske, K. D., J. Q. Chen, R. J. Naiman, and J. F. Franklin. 1997. Harvesting effects on microclimatic gradients from small streams to uplands in western Washington. Ecological Applications 7:1188-1200.

Busby, J. R., L. C. Bliss, and C. D. Hamilton. 1978. Microclimate control of growth rates and habitats of the boreal forest mosses Tomenthypnum nitens and Hylocomium splendens. Ecological Monographs 48:95-110.

Cadenasso, M. L., M. M. Traynor, and S. T. A. Pickett. 1997. Functional location of forest edges: gradients of multiple physical factors. Canadian Journal of Forest Research 27: 774-782.

Callaghan, T. V., N. J. Collins, and C. H. Callaghan. 1978. Photosynthesis, growth and reproduction of Hylocomium splendens and Polytrichum commune in Swedish Lapland. Oikos 31:73-88.

Castelle, A. J., A. W. Johnson, and C. Conolly. 1994. Wetland and stream buffer size requirements: a review. Journal of Environmental Quality 23:878-882.

Chen, J. Q., J. F. Franklin, and T. A. Spies. 1992. Vegetation responses to edge environments in old-growth Douglas-fir forests. Ecological Applications 2:387-396.

Chen, J. Q., J. F. Franklin, and T. A. Spies. 1995. Growingseason microclimatic gradients from clear-cut edges into old-growth Douglas-fir forests. Ecological Applications 5: 74-86.

Chen, J. Q., S. C. Saunders, T. R. Crow, R. J. Naiman, K. D. Brosofske, G. D. Mroz, B. L. Brookshire, and J. F. Franklin. 1999. Microclimate in forest ecosystem and landscape ecology: variations in local climate can be used to monitor and compare the effects of different management regimes. BioScience 49:288-297.

Clausen, E. 1964. The tolerance of hepatics to desiccation and temperature. Bryologist 67:411-417.

Clausen, J. C., K. Guillard, C. M. Sigmund, and K. M. Dors. 2000. Ecosystem restoration: water quality changes from riparian buffer restoration in Connecticut. Journal of Environmental Quality 29:1751-1761.

Clinnick, P. F. 1985. Buffer strip management in forest operations: a review. Australian Forestry 48:34-45.

Crawford, R. M. M. 1989. Studies in plant survival: ecological case histories of plant adaptation to adversity. Studies in ecology. Volume 11. Blackwell Scientific, Oxford, UK.

Darveau, M., P. Beauchesne, L. Belanger, J. Huot, and P.
Larue. 1995. Riparian forest strips as habitat for breeding birds in boreal forest. Journal of Wildlife Management 59: $67-78$.

Darveau, M., L. Belanger, J. Huot, E. Melancon, and S. DeBellefeuille. 1997. Forestry practices and the risk of bird nest predation in a boreal coniferous forest. Ecological Applications 7:572-580.

Darveau, M., P. Labbe, P. Beauchesne, L. Belanger, and J. Huot. 2001. The use of riparian forest strips by small mammals in a boreal balsam fir forest. Forest Ecology and Management 143:95-104.

Davies, P. E., and M. Nelson. 1994. Relationships between riparian buffer widths and the effects of logging on stream habitat, invertebrate community composition and fish abundance. Australian Journal of Marine and Freshwater Research 45:1289-1305.

Dong, J., J. Chen, K. D. Brosofske, and R. J. Naiman. 1998. Modelling air temperature gradients across managed small streams in western Washington. Journal of Environmental Management 53:309-321.

Dupuis, L., and D. Steventon. 1999. Riparian management and the tailed frog in northern coastal forests. Forest Ecology and Management 124:35-43.

Eckerberg, K. 1988. Clear felling and environmental protection: results from an investigation in Swedish forests. Journal of Environmental Management 27:237-256.

Esseen, P. A., and K.-E. Renhorn. 1998. Edge effects on an epiphytic lichen in fragmented forests. Conservation $\mathrm{Bi}-$ ology 12:1307-1317.

Forman, R. T. T. 1995. Land mosaics: the ecology of landscapes and regions. Cambridge University Press, Cambridge, UK.

Fries, C., O. Johansson, B. Pettersson, and P. Simonsson. 1997. Silvicultural models to maintain and restore natural stand structures in Swedish boreal forests. Forest Ecology and Management 94:89-103.

Fries, C., G. Linden, and E. Nillius. 1998. The stream model for ecological landscape planning in non-industrial private forestry. Scandinavian Journal of Forest Research 13:370 378.

Gregory, S. V., F. J. Swanson, W. A. McKee, and K. W. Cummins. 1991. An ecosystem perspective of riparian zones. BioScience 41:540-551.

Gustafsson, L., and L. Hansson. 1997. Corridors as a conservation tool. Ecological Bulletins 46:182-190.

Hagar, J. C. 1999. Influence of riparian buffer width on bird assemblages in Western Oregon. Journal of Wildlife Management 63:484-496.

Hägglund, B., and J.-E. Lundmark. 1981. Handledning i bonitering med Skogshögsskolans boniteringssystem. National Board of Forestry, Jönköping, Sweden.

Hallingbäck, T. 1996. Ekologisk katalog över mossor. Swedish Threatened Species Unit, Swedish University of Agricultural Sciences, Uppsala, Sweden.

Hansmann, E. W., and H. K. Phinney. 1973. Effects of logging on periphyton in coastal streams of Oregon. Ecology 54:194-199.

Hibbs, D. E., and P. A. Giordano. 1996. Vegetation characteristics of alder-dominated riparian buffer strips in the Oregon Coast Range. Northwest Science 70:213-222.

Holopainen, A. L., and P. Huttunen. 1992. Effects of forest clear-cutting and soil disturbance on the biology of small forest brooks. Hydrobiologia 243:457-464.

Jonsson, B. G. 1997. Riparian bryophyte vegetation in the Cascade mountain range, Northwest USA: patterns at different spatial scales. Canadian Journal of Botany 75:744761.

Jorgensen, E. E., T. J. Canfield, and F. W. Kutz. 2000. Restored riparian buffers as tools for ecosystem restoration in the MAIA: processes, endpoints, and measures of suc- 
cess for water, soil, flora, and fauna. Environmental Monitoring and Assessment 63:199-210.

Karlsson, H., J.-E. Lundmark, H. Sundqvist, B. Wahlgren, J. Jacobsson, and O. Johansson. 1999. Handbok i återväxtplanering. AssiDomän, Stockholm, Sweden.

Large, A. R. G., and G. E. Petts. 1994. Rehabilitation of river margins. Pages 401-418 in P. Calow and G. E. Petts, editors. The rivers handbook. Blackwell Scientific, Oxford, UK.

Machtans, C. S., M. A. Villard, and S. J. Hannon. 1996. Use of riparian buffer strips as movement corridors by forest birds. Conservation Biology 10:1366-1379.

Meiklejohn, B. A., and J. W. Hughes. 1999. Bird communities in riparian buffer strips of industrial forests. American Midland Naturalist 141:172-184.

MoDo. 1999. Guidelines for sustainable forestry. MoDo Skog, Örnsköldsvik, Sweden.

Murcia, C. 1995. Edge effects in fragmented forests: implications for conservation. Trends in Ecology and Evolution 10:58-62.

Murphy, M. L., J. Heifetz, S. W. Johnson, K. V. Koski, and J. F. Thedinga. 1986. Effects of clear-cut logging with and without buffer strips on juvenile salmonids in Alaskan streams. Canadian Journal of Fisheries and Aquatic Sciences 43:1521-1533.

Naiman, R. J., and H. Décamps. 1997. The ecology of interfaces: riparian zones. Annual Review of Ecology and Systematics 28:621-658.

Naiman, R. J., H. Décamps, and M. Pollock. 1993. The role of riparian corridors in maintaining regional biodiversity. Ecological Applications 3:209-212.

Newbold, J. D., D. C. Erman, and K. B. Roby. 1980. Effects of logging on macroinvertebrates in streams with and without buffer strips. Canadian Journal of Fisheries and Aquatic Sciences 37:1076-1085.

Nilsson, C., E. Nilsson, M. E. Johansson, M. Dynesius, G. Grelsson, S. Xiong, R. Jansson, and M. Danvind. 1993. Processes structuring riparian vegetation. Pages 419-431 in J. Menon, editor. Current topics in botanical research. Council of Scientific Research Integration, Trivandrum, India.

Norušis, M. J. 1993. SPSS for Windows, version 9.0. SPSS, Chicago, Illinois, USA.
Olsen, S. R. 1995. Climatic factors in eleven Norwegian forest edges. Pages 261-273 in A. Hyttinen, A. Kähkönen, and P. Pelli, editors. Multiple use and environmental values in forest planning. Proceedings of the International Summer Course. EFI Procedings. Volume 4. European Forest Institute, Tohmajärvi, Finland.

Pearson, S. F., and D. A. Manuwal. 2001. Breeding bird response to riparian buffer width in managed Pacific Northwest Douglas-fir forests. Ecological Applications 11:840853.

Pharo, E. J., and A. J. Beattie. 1997. Bryophyte and lichen diversity: a comparative study. Australian Journal of Ecology 22:151-162.

Pitkin, P. H. 1975. Variability and seasonality of the growth of some corticolous pleurocarpous mosses. Journal of Bryology 8:337-356.

Proctor, M. C. F. 1990. The physiological basis of bryophyte production. Botanical Journal of the Linnean Society 104: 61-77.

Raab, B., and H. Vedin, editors. 1995. Climate, lakes and rivers. SNA Publisher, Stockholm, Sweden.

SCA. 1998. Naturhänsyn vid avverkning. SCA Forest and Timber, Sundsvall, Sweden.

Swanson, F. J., and J. F. Franklin. 1992. New forestry principles from ecosystem analysis of Pacific Northwest forests. Ecological Applications 2:262-274.

Törnquist, K. 1996. Ecological landscape planning in Swedish forestry. Pages 189-196 in P. Hyttinen and A. Nilson, editors. Integrating environmental values into forest planning: Baltic and Nordic perspectives. Proceedings of the Nordic-Baltic Research Course, Räpina, Estonia.

Vitt, D. H. 1989. Patterns of growth of the drought tolerant moss, Racomitrium microcarpon, over a three year period. Lindbergia 15:181-187.

Wastenson, L., and N.-E. Nilsson, editors. 1990. National atlas of Sweden: the forests. National Board of Forestry, Jönköping, Sweden.

Wilcox, D., B. Dove, D. McDavid, and D. Greer. 1995-1996. UTHSCSA Image Tool for Windows version 2.00. University of Texas Health Science Center, San Antonio, Texas, USA.

Young, A., and N. Mitchell. 1994. Microclimate and vegetation edge effects in a fragmented Podocarp-broadleaf forest in New Zealand. Biological Conservation 67:63-72. 